\title{
Isolation and Molecular Identification of Some Blue-Green Algae (Cyanobacteria) from Freshwater Sites in Tokat Province of Turkey
}

\author{
Tunay Karan ${ }^{1 *}$, Ramazan Erenler ${ }^{2}$, Zekeriya Altuner ${ }^{3}$ \\ ${ }^{1}$ Division of General Biology, Department of Biology, Faculty of Arts \& Sciences, Gaziosmanpasa University, 60250 Tokat, Turkey \\ ${ }^{2}$ Division of Biochemistry, Department of Chemistry, Faculty of Arts \& Sciences, Gaziosmanpasa University, 60250 Tokat, Turkey \\ ${ }^{3}$ Department of Biology, Faculty of Science, Gaziosmanpasa University, 60250 Tokat, Turkey
}

\begin{tabular}{ll}
\hline A R T I C L E I N F O & A \\
Research Article & Col \\
Received 15 August 2017 & Accepted 20 September 2017 \\
\hline
\end{tabular}

Keywords:

Algae

16S rRNA

Cyanobacteria

Molecular identification

Phycocyanine

*Corresponding Author:

E-mail: biyo_tunay@hotmail.com

\section{A B S T R A C T}

Collected blue-green algae (cyanobacteria) from freshwater sites throughout Tokat province and its outlying areas were isolated in laboratory environment and their morphological systematics were determined and also their species identifications were studied by molecular methods. Seven different species of blue-green algae collected from seven different sites were isolated by purifying in cultures in laboratory environment. DNA extractions were made from isolated cells and extracted DNAs were amplified by using PCR. Cyanobacteria specific primers were used to amplify $16 \mathrm{~S}$ rRNA and phycocyanine gene regions using PCR. Phylogenetic identification of species were conducted by evaluation of obtained sequence analysis data by using computer software. According to species identification by sequence analysis, it was seen that molecular data supports morphological systematics.

DOI: https://doi.org/10.24925/turjaf.v5i11.1371-1378.1470

\section{Introduction}

Cyanoprokaryotes are unique among microorganisms due to having chlorophyll a and their ability to make photosynthesis (Singh et al., 2011). They have gram negative cell walls and their peptidoglycan layers are ranging in 10-200 $\mathrm{nm}$ of thickness (Gademan and Portman, 2008). Dominant pigments present in cyanobacteria are chlorophyll a, chlorophyll $\mathrm{c}$ and phycocyanine which contributing to their distinct bluegreen colorization. Additionally they have different kinds of color pigments such as $\beta$-carotene and xanthophyll. Also some cyanobacteria species contains phycoerythrin pigments which is one of phycobilin bilanes and attributed to red colorization (Altuner, 2010).

Cyanobacteria can either be unicellular or aggregates of many cells forming a colony. Those of unicellular cyanobacteria mostly assume forms of bacilli, discoidal, actinoidal or fibrillary shapes whereas colony forming cyanobacteria mostly assume forms of spherical shapes (Whitton and Potts, 2000). Certain cyanobacteria species contain special cells called as heterocyst which are smaller than akinete and responsible for fixating free nitrogen of air. These cells are among cells forming
Tallus fiber and only present in cyanobacteria (Sukatar, 2002; Altuner 2010). Morphological traits are taken as basis for classification of cyanobacteria. However, morphological traits might be altered due to changes in environmental and developmental conditions. Strain diversity in cultures can be inhibited by using elective culture conditions. These reasons are making the development of molecular techniques for identification of cyanobacteria a necessity (Lyra et al., 2001).

Most frequently used marker gene is 16S rRNA gene for both identification of microorganisms and evaluation of relationships between them. While $16 \mathrm{~S}$ rRNA gene contains many evolutionarily conserved sequences, many species specific variable sequences are also present in $16 \mathrm{~S}$ rRNA gene. Species level identification is possible by amplifying these variable sequences using PCR. Precise identifications of species of Geitlerinema strain PCC 9452 (Microcoleus sp. strain $10 \mathrm{MFX}$ ) and Oscillatoria limnetica have been shown by amplification of $16 \mathrm{~S}$ rRNA genes (Boyer et al., 2001). Cylindrospermum Kutz. Ex. Bornet et Flahault differentiated from Nostocacea family due to their terminal heterocysts and paraheterocystic 
akinetes and 45 taxa of this genus identified (Guiry and Guiry, 2014; Johansen et al., 2014). Even though less frequently used, some researchers are using protein coding gene regions of rpoB, rpoC1, recA, rpoD1 and nifH as alternative templates for phylogenetic analysis of cyanobacteria (Saker et al, 2005; Premanandh et al, 2006). In another study, strains of Synechococcus have been determined by phylogeny using phycocyanine gene sequences (Robertson et al, 2001). In this study it is aimed to isolate, purify and molecularly identify various cyanobacteria collected from different freshwater sites on riverbank of Yesilirmak in Tokat Province of Turkey.

\section{Material and Methods}

\section{Sample collection}

Seven different stations were chosen on pelagic sites of Yesilirmak riverbank throughout Tokat province of Turkey and its outlying freshwater branches. Coordinates of chosen sites were determined by using geographical positioning system (GPS) and presented in Table 1. Collected freshwater samples were transferred into $1 \mathrm{~L}$ plastic canisters and were delivered to microalgae culturing laboratory.

\section{Cyanobacteria Isolation}

Delivered freshwater samples were first tromped by filter paper (GF/C Filter, Whatman, GE Life Sciences, PA; USA) and transferred into petri dishes. Filtrated samples were sterilized under UV light for $10 \mathrm{~min}$ in a sterilization chamber. Samples in petri dishes were incubated in enrichment solution ( $\mathrm{F} / 2$ solution) until the identification stage and dishes were kept in acclimation chamber (Sanyo MLR 351, Sanyo, Tokyo, Japan) at $26^{\circ} \mathrm{C}$ under 2465 lux illumination with 12:12 hours light/dark cycle (Andersen, 2005; Teneva et al, 2012). Morphological traits were examined under light microscope (Olympus CX31-P, Olympus, Japan). Species going to be isolated were determined and mechanically isolated under inverted microscope by using micropipette and microinjection (Rai and Rajashekhar, 2016). Following the mechanical isolation, strains were inoculated into $1.5 \%$ agar and appropriate nutritional media (Bristol BG11 and $\mathrm{BG} 11^{\circ}$, HiMedia Labs, Mumbai, India) by using line inoculation method. Procedures were repeated until only one strain remain isolated and pured (Galhanoa et al, 2011).

\section{Morphological Characterization}

Morphological differentiations based on either strains were filamentous or unicellular and if filamentous strains contained heterocysts were conducted first. Widths and heights of examined strains were measured by using micrometer apparatus in microscope ocular and photographs were taken. Systematics of purified strains were done in accordance to algae database (accessed online at http://www.algaebase.org/).

\section{DNA Purifications}

Total DNA extractions from 50-100 mg wet cyanobacteria samples were conducted by using ZR Fungal/Bacterial DNA Extraction kit (Zymo Research,
Irvine, CA; USA) in accordance with manufacturer instructions. Amount and purity of extracted DNA were quality checked by using nanodrop spectrophotometry (DeNovix, Wilmington, DE; USA) at 260-280 nm wavelength absorbance.

\section{PCR Procedures}

Obtained genomic DNAs were first amplified by using universal bacterial primers for $16 \mathrm{~s}$ gene region for all the cyanobacteria samples. Universal bacterial primer that were used have sequences for forward primer as $27 \mathrm{~F}$ : 5'-AGA GTT TGA TCC TGG CTC AG-3' and for reverse primer as 1492R: 5'-TAC GCG CTA CCT TGT TAC GAC-3'. Afterwards, 16s gene region PCR amplification, phycocyanine gene region was conducted by using forward primer of PC $\beta F$ : 5'-GGC TGC TTG TTT ACG CGA CA-3' and reverse primer of PCaR: 5'CCA GTA CCA CCA GCA ACT AA-3' just for Anabaena oryzae and Nostoc linckia taxon. Roche FastStartTaq DNA Polymerase kit (Roche Life Sciences, Istanbul, Turkey) was used for PCR reactions. PCR mixtures were prepared in $0.2 \mathrm{ml}$ sterile PCR tubes by additions of following reagents: $2.5 \mu \mathrm{l} 2 \mathrm{mM} 10 \mathrm{x}$ PCR buffer; $0.75 \mu \mathrm{l} 10 \mathrm{mM}$ dNTP; $2.5 \mu \mathrm{l} 0.2 \mu \mathrm{M}$ 10x primers (separately for each primer); $0.25 \mu \mathrm{l} 2 \mathrm{U}$ Taq DNA Polymerase; $100 \mathrm{ng}$ genomic DNA. Total mixture volume add up to $25 \mu \mathrm{l}$ by filling with $\mathrm{ddH}_{2} \mathrm{O}$. DNA amplifications were done using thermal cycler (Bio-Rad Turkey, Istanbul, Turkey) in following configuration for 30 cycles: Initial denaturation at $95^{\circ} \mathrm{C}$ for $4 \mathrm{~min}$; Denaturation at $95^{\circ} \mathrm{C}$ for $55 \mathrm{sec}$; Annealing at $60^{\circ} \mathrm{C}$ for 45 sec; Extension at $72^{\circ} \mathrm{C}$ for a minute. At the last step of amplification, a final extension at $72^{\circ} \mathrm{C}$ for $7 \mathrm{~min}$ was applied. PCR products were subjected to electrophoresis inside $1.5 \%$ agarose gel by applying $80 \mathrm{~V}$ current for 45 min. Then, stained by ethidium bromide and screened under UV transilluminator cabin (Saker et al, 2005; Premanandh et al, 2006; Green et al, 2008).

\section{Sequencing and Phylogeny}

The PCR products of 16s rRNA and phycocyanin gene regions were sequenced and edited at REFGEN (Gene Research and Biotechnology Ltd. Sti., Ankara, TURKEY). Additional sequences (nineteen phycocyanin gene and seventeen 16s rRNA gene sequences, Table 2) for further phylogenetic analyses were acquired from GenBank (https://www.ncbi.nlm.nih.gov/genbank/).

All of 16s rRNA and phycocyanin genes sequences were aligned using the Clustal-W algorithm in GENEIOUS version 10.1.3 (http://www.geneious.com, Kearse et al., 2012).

Limnothrix redekei (HE974998.1) and Cyanothece sp. (CP002198.1) were used as outgroups in analyses. Phylogenetic trees were constructed using the maximum likelihood (ML) algorithm presented in RAxML plugin (http://www.geneious.com/plugins/raxml-plugin). The GTR+I+G evolutionary model of substitution was used for ML using parameters (base frequencies, rate matrix of substitution types, and shape of gamma distribution) estimated from the data and trees was assessed using 1000 bootstrap replicates. 
Table 1 GPS coordinates of research stations in Tokat province of Turkey

\begin{tabular}{c|lll}
\hline Station numbers & \multicolumn{1}{|c}{ Samples } & \multicolumn{1}{c}{ Location Names } & \multicolumn{1}{c}{ Coordinates } \\
\hline 1 & Geitlerinema carotinosum & TEIAS Building & $49^{\circ} 19^{\prime} 49.12^{\prime \prime} \mathrm{N}, 36^{\circ} 34^{\prime} 2.06^{\prime \prime} \mathrm{E}$ \\
2 & Nostoc linckia & State Hospital & $40^{\circ} 19^{\prime} 45.655^{\prime \prime} \mathrm{N}, 36^{\circ} 33^{\prime} 45.06^{\prime \prime} \mathrm{E}$ \\
3 & Oscillatoria limnetica & Songut Town Riverbank & $40^{\circ} 19^{\prime} 51.27^{\prime \prime} \mathrm{N}, 36^{\circ} 23^{\prime} 4.69^{\prime \prime} \mathrm{E}$ \\
4 & Chroococcus minutus & Kat Town Riverbank & $40^{\circ} 1740.19^{\prime \prime} \mathrm{N}, 36^{\circ} 1928.81^{\prime \prime} \mathrm{E}$ \\
5 & Cylindrospermum sp. & Campus NE region & $40^{\circ} 20^{\prime} 4.39^{\prime \prime} \mathrm{N}, 36^{\circ} 28^{\prime} 37.46^{\prime \prime} \mathrm{E}$ \\
6 & Phormidium sp. & Campus North region & $40^{\circ} 19^{\prime} 50.85^{\prime \prime} \mathrm{N}, 36^{\circ} 28^{\prime} 37.46^{\prime \prime} \mathrm{E}$ \\
7 & Anabaena oryzae & Campus Heat Center, North & $40^{\circ} 19^{\prime} 43.77^{\prime \prime} \mathrm{N}, 36^{\circ} 28^{\prime} 22.26^{\prime \prime} \mathrm{E}$ \\
\hline
\end{tabular}

Table 2 The list of GenBank data that we used for analysing the sequence data sets obtained from our 7 cyanobacteria samples

\begin{tabular}{|c|c|c|c|}
\hline & Organism name & $\underline{\text { Strain }}$ & Accession no \\
\hline & Chroococcus minutus & SAG 41.79 & KM019988.1 \\
\hline & Chroococcus minutus & CCALA 055 & GQ375047.1 \\
\hline & Chroococcus sp. & JJCV & AM710385.1 \\
\hline & Cylindrospermum alatosporum & SAG 43.79 & GQ287650.1 \\
\hline & Cylindrospermum muscicola & SAG 44.79 & KM019946.1 \\
\hline & Cylindrospermum stagnale & PCC 7417 & NR_114701.1 \\
\hline & Cylindrospermum stagnale & PCC 7417 & NR_102462.1 \\
\hline 16s rRNA & Geitlerinema carotinosum & AICB 37 & AY423710.1 \\
\hline & Geitlerinema pseudacutissimum & ladakh27 & КT315938.1 \\
\hline & Geitlerinema pseudacutissimum & P005 & JQ712608.1 \\
\hline & Geitlerinema sp. & Sai004 & GU935348.1 \\
\hline & Geitlerinema sp. & Sai001 & GU935345.1 \\
\hline & Limnothrix redekei (outgroup)* & CCAP $1459 / 29$ & HE974998.1 \\
\hline & Oscillatoria limnetica & MR1 & AJ007908.1 \\
\hline & Phormidium autumnale & JR16 & KT315936.1 \\
\hline & Pseudanabaena sp. & $1 \mathrm{tu} 24 \mathrm{~s} 9$ & AM259269.1 \\
\hline & Nostoc azollae & 0708 & CP002059.1 \\
\hline & Anabaena cylindrica & PCC 7122 & СР003659.1 \\
\hline & Anabaena cylindrica & PCC 7122, & NC_019771.1 \\
\hline & Anabaena planctonica & NIES-816 & AY702218.1 \\
\hline & Anabaena sphaerica & UTEX 'B 1616' & DQ439645.1 \\
\hline & Anabaena variabilis & ATCC 29413 & AY768465.1 \\
\hline & Aphanizomenon flos-aquae & ST97 & FN552349.2 \\
\hline & Aphanizomenon flos-aquae & AB2008/70 & FN552369.1 \\
\hline & Aphanizomenon sp. & TR183 & AY036900.1 \\
\hline Phycocyanin gene region & Cyanothece sp. (outgroup)* & PCC 7822 & CP002198.1 \\
\hline & Cylindrospermopsis raciborskii & - & AF426799.1 \\
\hline & Cylindrospermopsis raciborskii & Florida I & AY078438.1 \\
\hline & Cylindrospermopsis raciborskii & Florida F & AY078437.1 \\
\hline & Nostoc linckia & PACC 5085 & AY466120.1 \\
\hline & Nostoc sp. & PCC 7107 & СР003548.1 \\
\hline & Nostoc sp. & $\mathrm{C} 21$ & JN646756.1 \\
\hline & Nostoc sp. & $\mathrm{C} 19$ & JN646755.1 \\
\hline & Nostoc sp. & PCC 7120 & AY768464.1 \\
\hline & Nostoc sp. & MCC2741 & KT166439.1 \\
\hline
\end{tabular}




\section{Results}

\section{Morphological Observations}

According to morphological traits observed under light microscopy, following cyanobacteria strains were purified and their identifications were made. Systematics of purified strains are summarized in Table 3 below.

Chroococcus minutus (Kutz.) Nägeli: Cellular shapes were either ovoid or spherical and they were observed as either unicellular or as colonies of 2-4 cells. All cells were colorless. Those cells with envelopes were measured to have 6-15 $\mu \mathrm{m}$ diameter and those without envelopes were measured to have $4-10 \mu \mathrm{m}$ diameter as seen in Figure 1A.

Geitlerinema carotinosum (Geitler) Anagnostidis: Cells were organized as resembling fascicules and trichomes were observed as linear and slightly coiled with becoming thinner at the ends. Cells have sizes of 1.5-3 $\mu \mathrm{m}$ width and 3-9 $\mu \mathrm{m}$ height as seen in Figure 1B.

Anabaena oryzae F.E. Fritsch: Trichomes were observed as linear and without envelopes. Cells have sizes of 2.5-4 $\mu \mathrm{m}$ width and 4-8 $\mu \mathrm{m}$ height and have barrel shapes. Heterocysts have shapes of either spherical or ellipsoidal and positioned at or near to terminal ends. Heterocysts have sizes of 3.5-6 $\mu \mathrm{m}$ width and 6-8 $\mu \mathrm{m}$ height as seen in Figure 1C.

Oscillatoria limnetica Lemmermann: Trichomes were observed as either linear or slightly curved. Cells have sizes of 1.3-2.2 $\mu \mathrm{m}$ width and 4-12 $\mu \mathrm{m}$ height. Cell walls were notably become narrower in longitudinal plane and terminal cells were observed as circular. They contain no calyptra as seen in Figure 1D.

Phormidium sp. MBIC10025: Many trichomes were observed as gelatinous or strapped aggregates. They were observed as flowing or bound colonies. They have very thin envelopes or no envelopes. Cells have sizes of 1.2$2.3 \mu \mathrm{m}$ width and $1.2-3 \mu \mathrm{m}$ height as seen in Figure 1E.

Cylindrospermum sp. CENA33: Trichomes were observed as unclear aggregates. Heterocysts were observed at terminal ends and seen as spherical. Cells have sizes of 3-5 $\mu \mathrm{m}$ width and 4-6 $\mu \mathrm{m}$ height. Heterocysts have sizes of 5-7 $\mu \mathrm{m}$ width and 6-8 $\mu \mathrm{m}$ height. Akinetes were not observed as seen in Figure 1F.

Nostoc linckia PACC 5085: Cells have 3-4 $\mu \mathrm{m}$ width with barrel shapes and gelatinous with colorization of blue-green to brown. Heterocysts have 5-6 $\mu \mathrm{m}$ width. Akinetes have sizes of 6-7 $\mu \mathrm{m}$ width and 7-10 $\mu \mathrm{m}$ height and resembling spherical or slightly elongated shapes as seen in Figure 1G.

Cyanobacteria species require water, light, $\mathrm{CO}_{2}$ and simple inorganic compounds for survival (Hageman, 2011). However, cyanobacteria species can grow much faster in certain environmental conditions (Nidhi Gupta et al, 2002). For this reasons, there are specialized growth media for cyanobacteria culturing. In this study we also have defined the best growth media for these seven taxon. Almost each cyanobacteria species grown efficiently in different growth media. Bristol broth, BG11 (w/ $\left.\mathrm{NaNO}_{3}\right)$ and $\mathrm{BG} 11^{\circ}\left(\mathrm{w} / \mathrm{o} \mathrm{NaNO}_{3}\right)$ growth medias were prepared for culturing of isolated cyanobacteria strains. Bristol broth medium was used for culturing of Chroococcus minitus and Geitlerinema carotinosum strains. BG11 medium was used for Oscillatoria limnetica and Phormidium sp. MBIC10025 strains. BG $11^{\circ}$ medium was used for nitrogen fixating strains of Nostoc linckia PACC 5085, Anabaena oryzae and Cylindrospermum sp. CENA33. All cultures were induced at $25^{\circ} \mathrm{C}$ under 2465 lux illumination.

Table 3 The systematics information of purified cyanobacteria in our study

\begin{tabular}{l|lll}
\hline \multicolumn{1}{c|}{ Subclass } & \multicolumn{1}{c}{ Order } & \multicolumn{1}{c}{ Family } & \multicolumn{1}{c}{ Genus } \\
\hline Oscillatoriophycideae & Chroococcales & Chroococcaceae & Chroococcus \\
Oscillatoriophycideae & Oscillatoriales & Coleofasciculaceae & Geitlerinema \\
Nostocophycideae & Nostocales & Nostocaceae & Anabaena \\
Oscillatoriophycideae & Oscillatoriales & Oscillatoriaceae & Oscillatoria \\
Oscillatoriophycideae & Oscillatoriales & Oscillatoriaceae & Phormidium \\
Nostocophycideae & Nostocales & Nostocaceae & Cylindrospermum \\
Nostocophycideae & Nostocales & Nostocaceae & Nostoc \\
\hline
\end{tabular}

Table 4 GenBank accession numbers of Cyanobacteria species in this study.

\begin{tabular}{l|lll}
\hline \multicolumn{5}{c}{} & Phycocyanin sequence \\
\hline & Accession number & Species & Strain \\
2 & MF443183 & Anabaena oryzae & Ind3 \\
\hline \multicolumn{5}{l}{} & Nostoc linckia & PACC 5085 \\
\hline 1 & Accession number & 16s rRNA sequence \\
2 & MF423476 & Species & Strain \\
3 & MF423477 & Oscillatoria limnetica & MR1 \\
4 & MF423478 & Geitlerinema carotinosum & AICB 37 \\
5 & MF423479 & Cylindrospermum sp. & CENA 33 \\
\hline
\end{tabular}




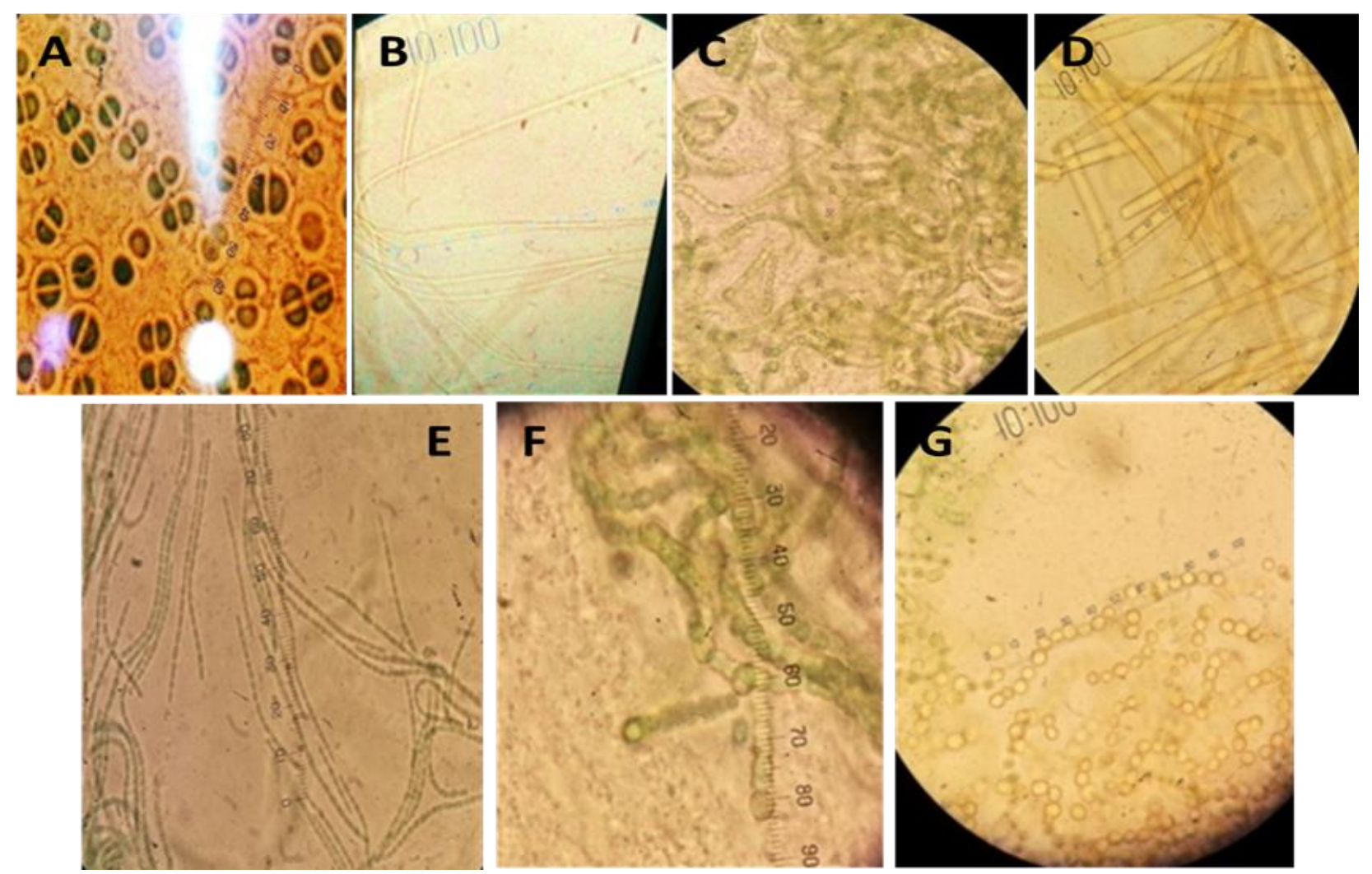

Figure 1 Light microscopy images of strains in our study. A) Chroococcus minutus, B) Geitlerinema carotinosum,

C) Anabaena oryzae, D) Oscillatoria limnetica, E) Phormidium sp., F) Cylindrospermum sp., G) Nostoc linckia

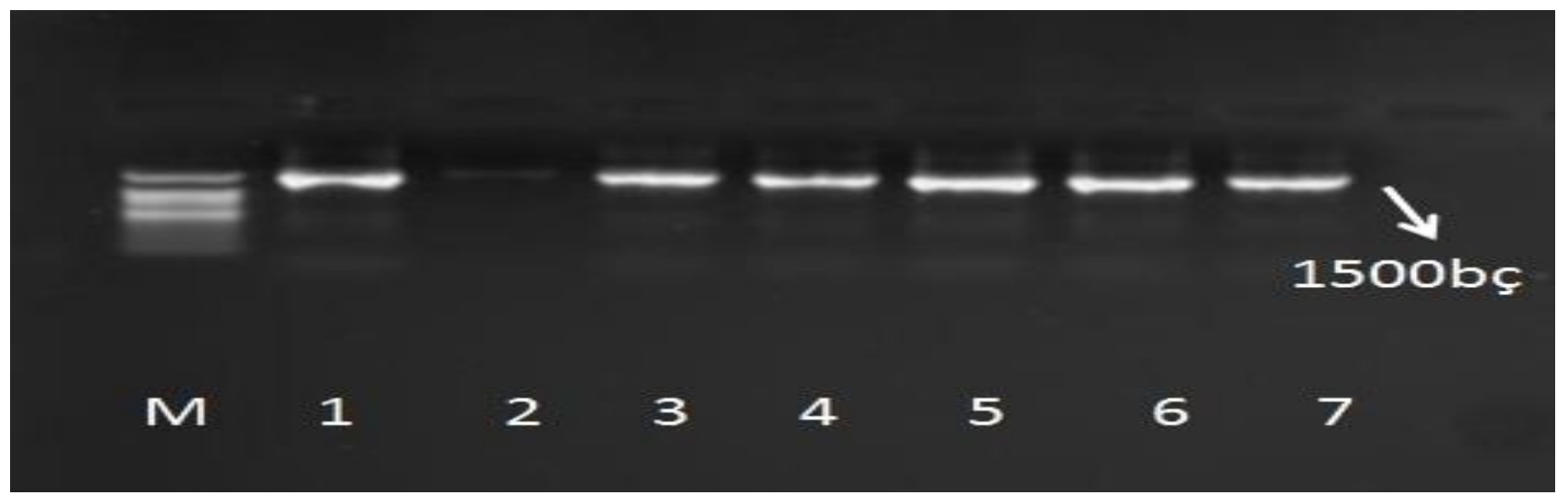

Figure 2: Agarose gel visualization of gene fragments amplified by 27F and 1492R primers. M stands for marker. 1: Chroococcus minitus, 2: Oscillatoria limnetica, 3: Geitlerinema carotinosum, 4: Nostoc linckia, 5: Phormidium sp., 6: Cylindrospermum sp., 7: Anabaena oryzae

\section{Results from Sequence and Phylogenetic Analyses}

PCR amplifications from genomic DNAs of purified strains using cyanobacteria specific universal bacterial primers were conducted as seen in Figure 2. Size of PCR product obtained from primers $27 \mathrm{~F}$ and $1492 \mathrm{R}$ was $\approx 1500$ bp (Figure 2). Afterwards, PCR amplifications of cyanobacteria phycocyanine gene region were conducted by using phycocyanine specific primers for just Anabaena oryzae and Nostoc linckia species. PCR product sizes for phycocyanine gene regions were observed almost as $\approx$ 300 bp. Firstly our obtained sequences data were combined with the data from the GenBank database (Table 2). Later separate phylogenetic analyses were performed for the two gene regions by using this combined data set. The Maximum likelihood tree, obtained from the analysis of the 16s rRNA sequences, showed the distinction of genus at high accuracy (Figure $3)$. This tree also placed the species, morphologically diagnosed in our study, in to the expected correct clades (Figure 3). On the other hand, maximum likelihood tree, obtained from the phylogenetic analysis of the sequences belongs to the phycocyanin gene region, supported the morphological description of our cyanobacteria samples with a molecular point of view, although the clades were not fully separated (Figure 4). GenBank accession numbers of Cyanobacteria species in this study are given in Table 4. 


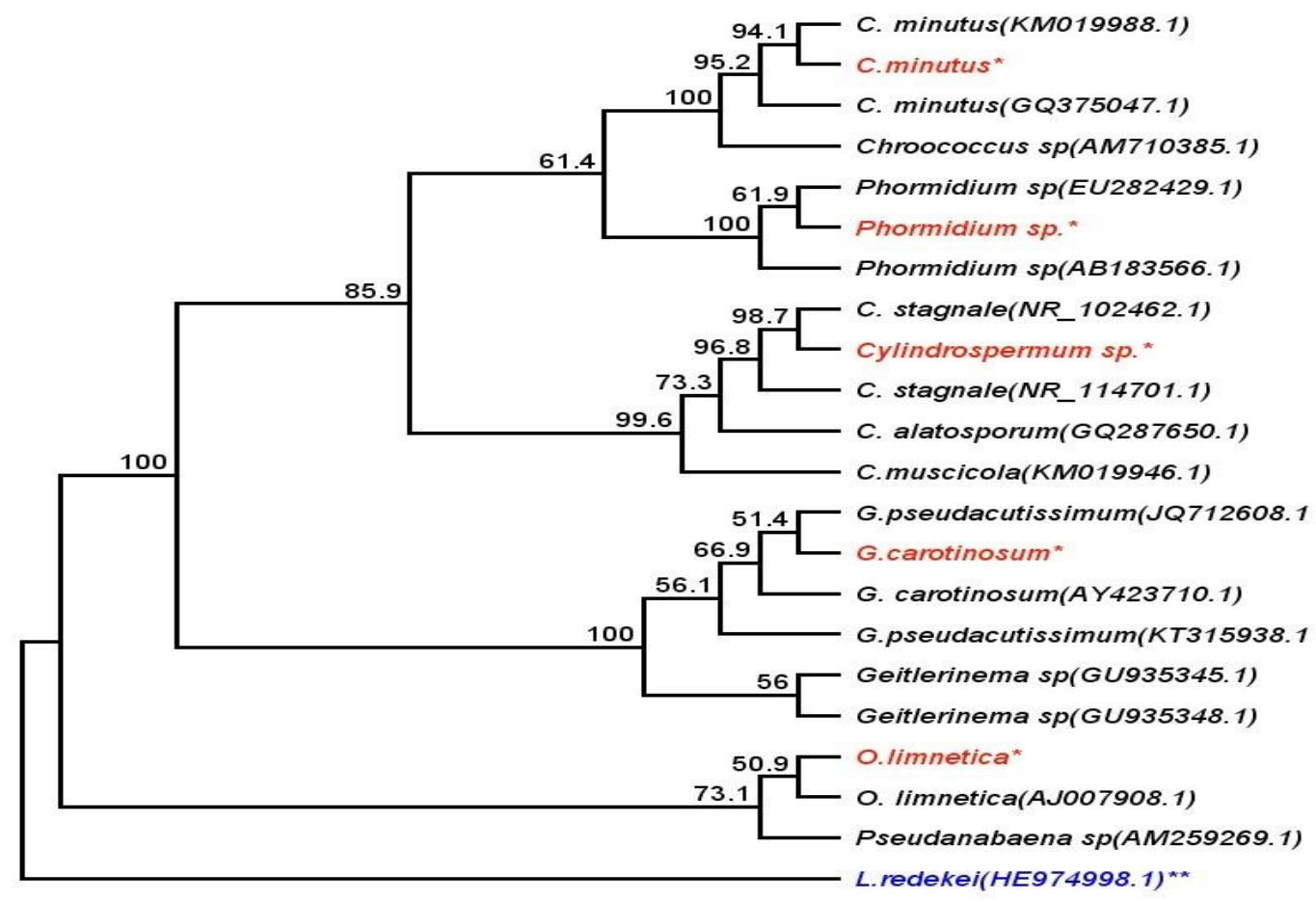

Figure 3 Maximum Likelihood tree based on 16S rRNA gene sequences (1500 bp). (Sequences from other species were obtained from GenBank. The examples signed with *and red colour are the data of our study from Tokat province. The example signed with ** and blue colour is out group, Limnothrix redekei CCAP 1459/29). Node robustness was assessed by performing 1000 bootstrap replications.

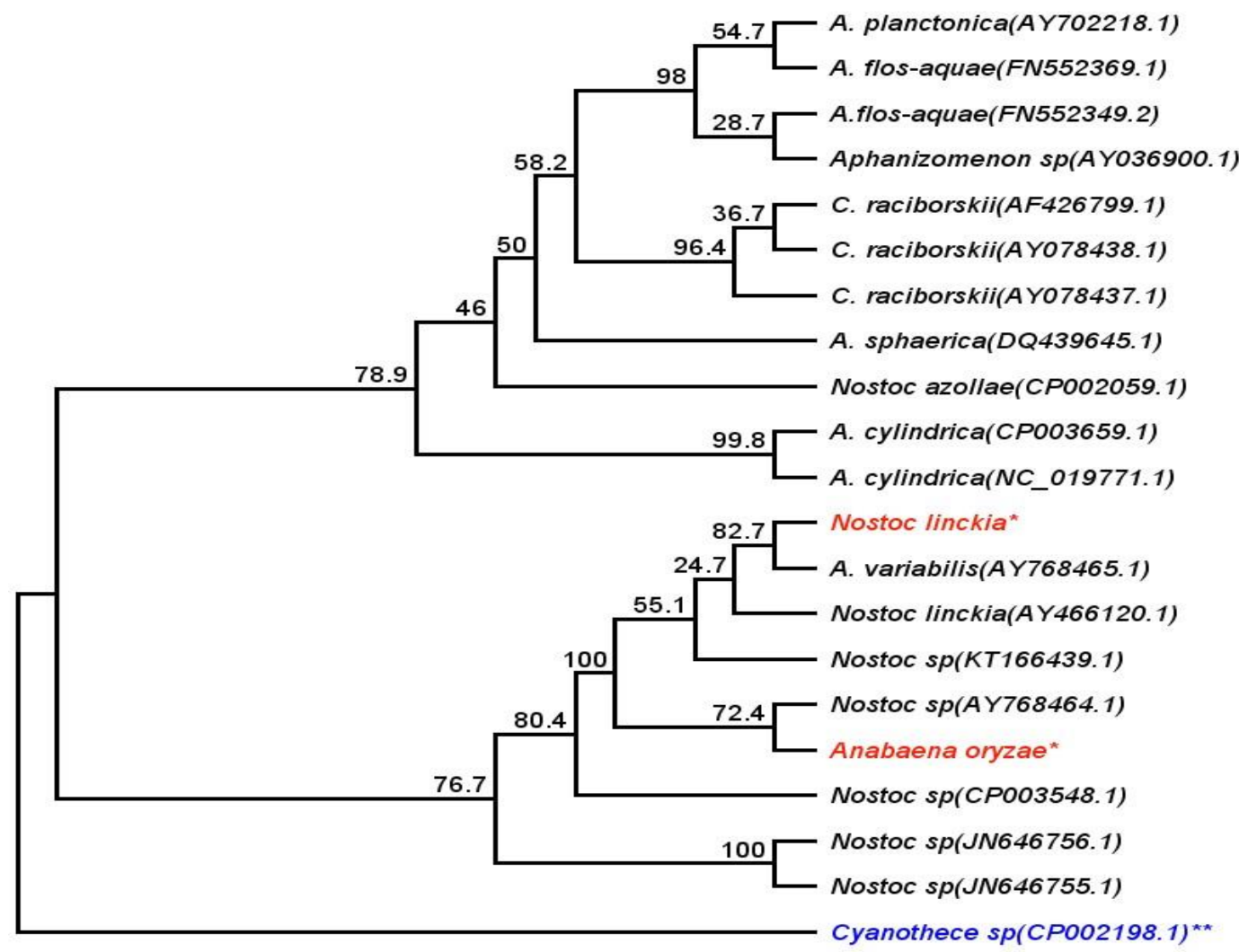

Figure 4 Maximum Likelihood tree based on Phycocyanin gene region. (Sequences from other species were obtained from GenBank. The examples signed with * and red colour are the data of our study from Tokat province. The example signed with $* *$ and blue colour is out group, Cyanothece sp. (CP002198.1)). 


\section{Discussion}

Taxonomy and classification of cyanobacteria species have been made according to cell morphology since $19^{\text {th }}$ century. However, many species identified by morphological traits are not concise enough and numerous genus need major revisions. Recently, researchers are highlighting the importance of molecular characterization of bacteria for concise results (Wehr and Sheath, 2003; Hasler et al, 2012). Recent approaches on cyanobacteria taxonomy are multidisciplinary methods including combination of morphology and ecology coupled with molecular characterization methods. Therefore, molecularly identified species must be in accord with phenotypic and ecological data (Hoffmann et al, 2005; Komarek et al, 2010; Komarkova et al, 2010). Filamentous cyanobacteria such as Geitlerinema, Microcoleus and Phormidium species have been taxonomically identified using both morphological and molecular characterizations. Notably these genus and respective species are mistaken morphologically to each other and specie clarifications were made by comparing $16 \mathrm{~S}$ rRNA sequences (Hasler et al, 2012). There are many studies conducted in Turkey in order to determine algae flora of Turkey (Ulcay, 2005). Nonetheless, molecular characterization studies of cyanobacteria species are quite few. Yuksel et al. (2009) were conducted a pioneer study in molecular characterization of cyanobacteria in Izmir province of Turkey. In their study researcher first isolated and purified 4 cyanobacteria species from thermal spring sites located in Izmir province of Turkey and molecularly identified these species on $16 \mathrm{~S}$ rRNA sequences by using specific $27 \mathrm{~F}$ and $809 \mathrm{R}$ primers for PCR amplifications. Nevertheless, there is still not enough studies present in molecular characterizations of cyanobacteria in Turkey and literature has mostly morphological systematic studies.

\section{Conclusion}

Our study is important as being an addition and a contribution to fill this gap about the molecular characterization of cyanobacteria in literature. With this study, isolation and purification of cyanobacteria species present in freshwater sites in Tokat province of Turkey were achieved for the first time. Morphological systematics of purified strains were conducted according to their morphological traits. Molecular systematic data of cyanobacteria species were obtained by using molecular characterization methods. Luckily, the results of molecular characterization have supported the morphological classification results of seven cyanobacteria species in this study. So the results related to the molecular analyses and the morphological description were in harmony, which did not create confusion in this study. This may not always be the case. Sometimes morphological systematic study results with molecular systematic study results may not support each other. It may be a little more difficult to do systematic and species diagnosis in this kind of situations. However, when doing classification studies, exploiting molecular genetic analysis as a kind of character is a necessity for the identification of suspicious taxa.

All in all, we believe that this study is a valuable addition to recent cyanobacteria literature by combining multidisciplinary approaches.

\section{Acknowledgements}

This work is supported by Gazi Osman Paşa University under the research project (Number: 2014/95).

\section{References}

Altuner Z. 2010. SistematikBotanik-I. $8^{\text {th }}$ Edt, p.202, Aktif Yayınevi, Istanbul, Turkey.

Andersen AR. 2005. Algal Culturing Techniques. p.505, Academic Press, Phycological Society of America; USA.

Boyer SL, Flechtner VR, Johansen, JR. 2001. Is the 16S-23S rRNA Internal Transcribed Spacer Region a Good Tool for Use in Molecular Systematics and Population Genetics? A Case Study in Cyanobacteria. Mol Biol Evol. 18(6): 1057-1069.

Gademan K, Portman C. 2008. Secondary metabolites from Cyanobacteria; complex structures and powerful bioactivities. Cur Org Chem. 12: 326-341.

Galhanoa V, Santosa H, Oliveirab MM, Gomes-Laranjoa J, Peixotoc F. 2011. Changes in fatty acid profile and antioxidant systems in a Nostocmuscorum strain exposed to the herbicide bentazon. Proc Biochem. 46:2152-2162.

Green SJ, Blackford C, Bucki P, Jahnke LL, Prufert-Bebout L. 2008. A salinity and sulfate manipulation of hypersaline microbial mats reveals stasis in the cyanobacterial community structure. The ISME Journal. 2:457-470.

Guiry MD, Guiry GM. 2014. AlgaeBase. World-wide electronic publication, National University of Ireland, Galway, IR. http://www.algaebase.org/(accessed on 02 January 2014).

NidhiGupta ASB, Bhaskar PV, and Rao L. 2002. Growth Characteristics and toxin production in batch cultures of Anabaena flos-aqaue: effects of culture media and duration. World J Microbio Biotech. 18:29-35.

Hageman M. 2011. Molecular biology of cyanobacterial salt acclimation. FEMS Microbiol, 35(1):87-123.

Hasler P, Dvořák P, Johansen JR, Kitner M, Ondřej V, Poulíčková A. 2012. Morphological and molecular study of epipelic filamentous genera Phormidium, Microcoleus and Geitlerinema (Oscillatoriales, Cyanophyta/Cyanobacteria). Fottea. 12:341356.

Hoffmann L, Koma'rek J, Kastovsky J. 2005. System of cyanoprokaryotes (cyanobacteria). Algol Stud. 117:95-115.

Johansen JR, Bohunická M, Lukešová A, Hrčková K, Vaccarino MA, Chesarino NM. 2014. Morphological and Molecular Characterization within 26 strains of the Genus Cylindrospermum (Nostocaceae, Cyanobacteria), With Descriptions of Three New Species. J Phycol. 50:187-202.

Kearse M, Moir R, Wilson A, Stones-Havas S, Cheung M, Sturrock S, Buxton S, Cooper A, Markowitz S, Duran C, Thierer T, Ashton B, Mentjies P, Drummond A. 2012. Geneious Basic: an integrated and extendable desktop software platform for the organization and analysis of sequence data. Bioinformatics. 28(12): 1647-1649

Komarek J. 2010. Recent changes (2008) in cyanobacteria taxonomy based on a combination of molecular background with phenotype and ecological consequences (genus and species concept). Hydrobio. 639:245-259.

Komarkova J, Jezberova J, Koma'rek O, Zapomelova E. 2010. Variability of Chroococcus (Cyanobacteria) morphospecies with regard to phylogenetic relationships. Hydrobio. 639:69-83.

Lyra C, Suomalainen S, Gugger M, Vezie C, Sundman P, Paulin L, Sivonen K. 2001. Molecular characterization of planktic cyanobacteria of Anabaena, Aphanizomenon, Microcystis and Planktothrix genera. Int J Syst Evol Microbiol. 51:513-526. 
Premanandh J, Priya B, Teneva I, Dzhambazov B, Pradaharan D, Uma L. 2006. Molecular Characterization of Marine Cyanobacteria from the Indian Subcontinent Deduced from Sequence Analysis of the Phycocyanine Operon (cpcB-IGScpcA) and 16S-23S ITS Region, J Microbio. 44(6):607-616.

Rai SV, Rajashekhar M. 2016. Effect of $\mathrm{pH}$, Salinity and Temperature on the Growth of Six Species of Cyanobacteria Isolated from Arabian Sea Coast of Karnataka. IJBST. 9(1):1-6.

Robertson BR, Tezuka N, Watanabe MM. 2001. Phylogenetic analyses of Synechococcus strains (cyanobacteria) using sequences of 16S RDNA and part of the phycocyanine operon reveal multiple evolutionary lines and reflect phycobilin content. Int J SystEvolMicrobio. 51:861-871.

Saker ML, Jungblut AD, Neilan BA, Rawn DF, Vasconcelos VM 2005. Detection of microcystinsynthetase genes in health food supplements containing the freshwater cyanobacterium Aphanizomenonflos-aquae. Toxicon. 46(5):555-562.

Singh RK, Tiwari SP, Rai AK, Mohapatra TM. 2011. Cyanobacteria: an emerging source for drug discovery. J Antibio. 64:401-412.
Sukatar A. 2002. Alg Kültür Yöntemleri. EU Basımevi, ISBN: 184:168, Izmir, Turkey.

Teneva I, Stoyanov P, Belkinova D, Dyulgerova ID, Mladenov R, Dzhambazov B. 2012. Production of cyanobacterial toxins from two Nostoc species (Nostocales) and evaluation of their cytotoxicity in vitro. J BioSci Biotech. 1(1):33-43.

Ulcay SO. 2005. Distribution of Blue-Green algae species in Manisa and around the hot springs. (Abstract in English). MSc thesis, Celal Bayar University, Manisa, Turkey.

Wehr JD, Sheath RG. 2003. Freshwater Algae of North America: Ecology and Classification. p.905, Academic Press, USA.

Whitton BA, and Potts M. 2000. The Ecology of Cyanobacteria: Their Diversity in Time and Space.p.669, Kluwer Academic Publisher, USA.

Yuksel K, Demirel Z, Kocyigit A, Sukatar A. 2009. İzmir İlinde Bulunan Termal Sularda Gelişen Bazı Termofilik Mavi-Yeşil Alglerin Siyanobakterilerin) İzolasyonu ve Moleküler Tayini (Article in Turkish, Abstract in English). EU J Fish Aqua Scie. $4: 267-270$. 